\title{
Growth and Yield Performance of Cowpea (Vigna Unguiculata (L.) Walp) as Influenced by Row-Spacing and Period of Weed Interference in South-West Nigeria
}

\author{
Joseph Adigun $^{1}$, A. O. Osipitan ${ }^{1}$, Segun Toyosi Lagoke ${ }^{1}$, Raphael Olusegun Adeyemi ${ }^{1}$ \\ $\&$ Stephen Olaoluwa Afolami ${ }^{1}$ \\ ${ }^{1}$ College of Plant Science and Crop Production, Federal University of Agriculture, P.M. B. 2240, Abeokuta, \\ Ogun State, Nigeria \\ Correspondence: Raphael Olusegun Adeyemi, Department of Plant Physiology and Crop Production, Federal \\ University of Agriculture, Abeokuta, Nigeria. Tel: 234-806-834-9022. E-mail: adeyemiolusegun3@gmail.com
}

Received: December 18, 2013 Accepted: January 14, 2014 Online Published: March 15, 2014

doi:10.5539/jas.v6n4p188 URL: http://dx.doi.org/10.5539/jas.v6n4p188

\begin{abstract}
Weed problem appears to be the most deleterious factor causing between 25 and $60 \%$ reduction in potential yield of cowpea. Field trials were therefore conducted to study the effect of inter-row spacing and period of weed interference on growth and yield of cowpea (Vigna unguiculata (L) Walp) at the Teaching and Research Farm of the Federal University of Agriculture, Abeokuta $\left(07^{\circ} 15^{\prime} ; 03^{\circ} 25^{\prime} \mathrm{E}\right)$ in South Western Nigeria during the early and late wet seasons of 2009. The experiment consisted of eight main plots of weed interference which included initial weed removal for 3, 6, 9, and 12 weeks after sowing (WAS) and subsequently weed -infested until harvest as well as initial weed infestation for corresponding periods and thereafter kept weed free until harvest. There were also sub-plot treatments of three inter-row spacing of 60,75 , and $90 \mathrm{~cm}$. All treatments in different combinations were laid out in a split-plot design with three replications. In both trials, the use of inter-row spacing of $60 \mathrm{~cm}$ resulted in significant reduction in weed growth as evident in lower weed dry matter production and subsequent higher cowpea pod and grain yields than those of 75 and $90 \mathrm{~cm}$ inter-row spacing. Initial weed infestation of up to 3 WAS did not have any adverse effect on crop growth and cowpea grain yields provided the weeds were subsequently removed. On the other hand, cowpea grain yield loss was not significantly averted by keeping the crop weed free for only 3 WAS without subsequent weed removal. In this study, initial weed-infestation for 6 WAS and beyond significantly depressed various crop growth parameter and cowpea grain yield compared with the crop kept weed free throughout its life cycle. In order to obtain optimum yields similar to that of the weed free cowpea field, it was required to keep the crop weed free for 6 WAS and beyond. However, frequent weeding beyond 9 weeks after sowing did not improve cowpea yield significantly and as a matter of fact it may even result in reduction of cowpea grain yield due to mechanical damage of hoe weeding. The practical implication of this finding is that early weeding starting from 3 WAS is very crucial for cowpea production while the critical period of weed removal for optimum yield in cowpea is between 3 and 9 WAS in the forest-savannah transitional zone of south Western Nigeria.
\end{abstract}

Keywords: inter-row spacing, weed interference growth and yield of cowpea

\section{Introduction}

Cowpea (Vigna unguiculata (L) Walp) is a crop of tremendous economic value being a major source of protein in West and Central Africa where more than $60 \%$ of the world's cowpea is being produced. Rural families derive food and animal fodder (Tarawali et al., 1997; Asiwe, 2007) as well as cash from the production of this crop (Quin, 1997). In many parts of West Africa, cowpea is a popular staple food utilized to fortify cassava, plantain, cereal-based meals and yoghurt (Henshaw et al., 2005). The chemical composition of cowpea is similar to that of most edible legumes. It contains about $24 \%$ protein, $62 \%$ soluble carbohydrate and small amount of other nutrients.

Apart from it's role in controlling soil erosion and fixing atmospheric nitrogen into the soil, thereby reducing nitrogen requirement for its growth (Langdale et al., 1997); cowpea is also a food security crop in the semi-arid 
zone of West and Central Africa which ensures subsistence food supply even in the dry years. It is adapted to stressful environment where other crops either fail or do not perform well.

World estimated annual cowpea production was put at 4.5 million metric tonnes from an estimated land area of 14 million hectares with Nigeria being the largest producer with an annual production of 2.4 million metric tonnes from an estimated land area of 5 million hectares. Traditionally, the production centres of this crop are in guinea and sudan savannah ecologies but in recent years cultivation of this crop has spread to the forest and derived savannah ecologies for which a number of varieties have been developed (Anonymous, 1992).

Although there is a great potential for cowpea production in South Western Nigeria, the yields obtained by farmers are generally low due to high level of diseases and pest infestations (Asiwe, 2007), lack of knowledge of good cultural practices, use of local varieties which are generally low yielding coupled with low soil fertility and weed management problem.

Of all the constraints limiting the production of cowpea in Nigeria, weed problem appears to be the most deleterious resulting in various degrees of yield losses ranging from 50-86\%; (Akobundu, 1979; Le et al., 2004). Apart from direct effect on yield and quality reduction, commong weed species such as Portulaca oleraceae; Solanum nigram (L) and Amaranthus spinosus (L) have been reported to serve as reservoir hosts for various pests and diseases (Alegbejo, 1987).

A number of studies have shown that increased crop density would decrease the magnitude of effect of weed competition with crops (Street et al., 1981; Teasday \& Frank, 1983; Adigun, 1992; Adigun 2002). Studies with soyabean by Cooper (1995) indicated that the semi dwarf soybean cultivars produced greater yield at a very narrow spacing of $17 \mathrm{~cm}$ with little advantage over standard cultivars at $75 \mathrm{~cm}$ row spacing and low plant densities. The semi dwarf lines produced relatively higher yields at the narrowest row spacing. Similarly in groundnut, yields increased with better competition against weeds obtained by growing the crops in narrow rows (Buchaman et al., 1976). Burnside and Juricek (1967) also observed that soyabean population of 98000; 196,000 and 390,000 plant/ha gave weed dry matter production of 2,259,1,425 and 1,175 kg/ha, respectively; an effect attributed to earlier and more vigorous shading and better competitive advantage in more dense crop population, using snap beans, planted at constant density of 15 to $46 \mathrm{~cm}$ suppressed weed growth more than that of $91 \mathrm{~cm}$ row. Biswan et al. (2002) reported that population density had significant effect on cowpea pod and seed yields while Aliyu (2007) observed that densely intercropped cowpea with millet could reduce Striga emergence thereby increasing grain yield. Adigun and Lagoke (1994) reported a 50-94\% reduction in groundnut pod yield due to unchecked weed growth throughout the crop life cycle.

The impact of weeds on yields of crops varies with the characteristics of crop, the weed species, weed density, the environment, the stage of crop growth and duration of crop exposure to weeds (Dowson et al., 1973). Although many competitive studies (Friesen, 1979; Adigun et al., 1992; Adigun et al., 1994; Adigun \& Lagoke 2003; Usman et al., 2002) have been conducted in the temperate and tropical regions between field and indigenous population of weeds, there is at present paucity of information on the effect of row spacing and period of weed interference on growth and yield of cowpea.

The objective of the present study is to evaluate the effect of inter-row spacing and period of weed interference on growth and yield of cowpea in South Western Nigeria. Such study will enable the practicing farmer to decide on the appropriate row spacing to be adopted in order to reduce the menace of weeds and the critical period of weed removal for optimum yield and profitability.

\section{Materials and Methods}

\subsection{Description of Experimental Site}

Field experiments were conducted to evaluate the effects of inter-row spacing and period of weed interference on growth and yield of cowpea at the Teaching and Research Farm of the Federal University of Agriculture, Abeokuta $\left(7^{\circ} 15^{\prime} \mathrm{N}, 3^{\circ} 25^{\prime} \mathrm{E}\right)$, in South Western Nigeria during the early (April-July) and late (August - October) cropping season of 2009. The location is characterised by a bimodal rainfall pattern with peaks usually in July and September and short dry spell in August with annual mean of about $1300 \mathrm{~mm}$ and a mean temperature of about $27^{\circ} \mathrm{C}$. The soils of the experimental sites were freely drained loamy sand with a $\mathrm{pH}$ of between 6.8 and 7.11 , organic carbon of $0.62-0.88 \%$, total nitrogen of $0.07-0.17 \%$ and available $\mathrm{P}$ of $20.10-20.40 \%$.

\subsection{Treatment and Experimental Design}

In both seasons the experiment consisted of eight main plots of weed interference periods which included initial weed removal for 3, 6, 9 and 12 weeks after sowing and subsequently kept weed-infested until harvest as well as initial weed infestation for corresponding periods and thereafter kept weed free until harvest. There were also 
sub-plot treatments of inter-row spacings of $60,75 \& 90 \mathrm{~cm}$; all intra-spaced at $30 \mathrm{~cm}$. All treatments in different combinations were laid out in a Split-plot design with three replications.

\subsection{Land Preparation and Crop Management}

The land was ploughed and disc- harrowed at two weeks interval. Inorganic fertilizers were broadcast at the rate of $45 \mathrm{~kg} /$ ha each of $\mathrm{P}_{2} \mathrm{O}_{5}$ and $\mathrm{K}_{2} \mathrm{O}$ before harrowing. Gross and net plot sizes were $(3 \times 4.5) \mathrm{m}^{2}$ and $(1.5 \times 3.0)$ $\mathrm{m}^{2}$, respectively. Seeds of cowpea (var. Ife Bimpe) were sown at the rate of two to four seeds per hole and later thinned to two per stand. Weed removal was carried out using the West African hand-hoe. Insecticides and fungicides were applied at the onset of flowering and subsequently fortnightly until pod maturity to protect the plants against insect and disease damage.

\subsection{Parameters Measured and Data Analysis}

Weed dry matter production at harvest, crop vigour score number of leaves per plant, canopy diameter, number of pods per plant, pod yield, 1000 seed grain weight were some of the parameters used to evaluate the performance of the treatments. Crop vigour score was taken by visual observation based on scale $0-10$, where 0 represented plots with crops completely killed and 10 represented plots with the most vigorous growing and healthy crop. At each time of weed removal, weed density and fresh weight were taken from quadrat of $1 \mathrm{~m} \times 1 \mathrm{~m}$ randomly placed in the central rows of the plots. Weed density was taken by physically counting the number of weeds which were then cleaned and oven dried to constant weight to get the weed dried matter production.

All parameters were taken and subjected to analysis of variance. The treatment means were compared using least significant different (LSD) where F values showed significance.

\section{Results and Discussion}

\subsection{Effect of Inter-Row Spacing on Weed Dry Matter Production, Growth and Yield of Cowpea}

The common weeds at the sites of the trials which included all categories of weeds and their levels of infestation are presented in Table 1. The common broad leaved weed species were: Euphorbia heterophyllia Linn; Talinum triangulare (Jacq) Wild; Amaranthus spinosus (L.); Acanthospermum hispidium DC; Boerhavia coccinea (Mill); Boerhavia diffusa (L).

Some grass weed species present also include Digitaria ciliaris (Ret) kock; Rottboellia cochinensis (Lour) Clayton; Panicum maximum (Jacq); Cynodon dactylon (L.) Gaertn and Imperata cylindrical (L.). While the sedges included Cyperus spp. 
Table 1. Common weed species found on the experimental sites during the course of study and their level of infestation in early and late wet seasons of 2009

\begin{tabular}{|c|c|c|}
\hline \multirow[b]{2}{*}{ Weed Species } & \multicolumn{2}{|c|}{ Level of infestation } \\
\hline & Early season & Late season \\
\hline \multicolumn{3}{|l|}{ Broad Leaved } \\
\hline Euphorbia heterophylla Linn & $* * *$ & $* * *$ \\
\hline Euphorbia hirta (L) & $*$ & $*$ \\
\hline Talinum triangulare (Jacq) Walid & $* * *$ & $* * *$ \\
\hline Chromolaena odorata (L) & $*$ & $*$ \\
\hline Tridax procumbens Linn & $* *$ & $* *$ \\
\hline Senna hirsute (Linn)Irwin & $*$ & $*$ \\
\hline Amaranthus spinousus (1.) & $* *$ & $* *$ \\
\hline Amaranthus viridis (1.) & * & $*$ \\
\hline Acanthospermum hispidium DC & $* *$ & $* *$ \\
\hline Boerhavia coccinea Mill & $* * *$ & $* * *$ \\
\hline Boerhavia diffusa l. & $* *$ & $* *$ \\
\hline Hyptis lancoeolata Poir & $*$ & $*$ \\
\hline \multicolumn{3}{|l|}{ Tithonia diversifolia (Hemsl.) A. Gray } \\
\hline \multicolumn{3}{|l|}{ Grasses } \\
\hline Digitaria ciliaris (Ret) Kock & $*$ & $*$ \\
\hline Imperata cylinrica (L.) & $*$ & $*$ \\
\hline Commelina bengalensis (L.) & $*$ & $*$ \\
\hline Rottbeollia cohinchinesis (Lour) Clayton & $*$ & $*$ \\
\hline Planicum maximum Jacq & $*$ & $*$ \\
\hline Cynodon dactylon (L.) Geartn & $* *$ & $* *$ \\
\hline Branchiaria lata Hubb (Schum) & $* *$ & $* *$ \\
\hline \multicolumn{3}{|l|}{ Sedges } \\
\hline Cyperus rotundus (L.) & $*$ & - \\
\hline Cyperus esculentus (L.) & $* *$ & $* *$ \\
\hline
\end{tabular}

*** High infestation $(60-90 \%)$.

** Moderate infestation (40-50\%).

* Low infestation $(1-39 \%)$.

Inter-row spacing had significant effect on canopy height at 9 weeks after sowing (WAS) in the early wet season of 2009 in which, inter-row spacing of $60 \mathrm{~cm}$ produced significantly taller canopy height than those of 75 and $90 \mathrm{~cm}$ inter-row spacing. Similarly, canopy diameter was significantly affected by inter-row spacing at 9 WAS in the early wet season where inter-row spacing of $60 \mathrm{~cm}$ produced significantly higher canopy diameter than those of 75 and $90 \mathrm{~cm}$ inter-row spacing (Tables 2). Number of leaves per plant and leaf area also showed similar trend although there was no significant difference among the inter-row spacing in this case (Table 3 ). 
Table 2. Effect of period of weed interference and inter-row spacing on canopy height and canopy diameter early and late seasons

\begin{tabular}{lllll}
\hline \multirow{2}{*}{ Treatments } & \multicolumn{2}{c}{ Canopy height $(\mathrm{cm})$} & \multicolumn{2}{c}{ Canopy diameter $(\mathrm{cm})$} \\
\cline { 2 - 5 } & $\begin{array}{l}\text { Early season } \\
9 \mathrm{WAS}\end{array}$ & $\begin{array}{l}\text { Late season } \\
9 \mathrm{WAS}\end{array}$ & $\begin{array}{l}\text { Early season } \\
9 \mathrm{WAS}\end{array}$ & $\begin{array}{l}\text { Late season } \\
9 \mathrm{WAS}\end{array}$ \\
\hline Period of Weed Interference & & & & \\
Initial weed removal for 3WAS & $53.28 \mathrm{~d}$ & $53.94 \mathrm{c}$ & $34.52 \mathrm{~b}$ & $36.69 \mathrm{~cd}$ \\
Initial weed removal for 6WAS & $56.53 \mathrm{bcd}$ & $54.57 \mathrm{c}$ & $31.77 \mathrm{~b}$ & $39.94 \mathrm{bc}$ \\
Initial weed removal for 9WAS & $53.9 \mathrm{~cd}$ & $57.2 \mathrm{bc}$ & $38.23 \mathrm{a}$ & $43.68 \mathrm{a}$ \\
Initial weed removal for 12WAS & - & - & - & - \\
Initial weed infestation for 3WAS & $55.50 \mathrm{~cd}$ & $55.48 \mathrm{bc}$ & $36.20 \mathrm{~b}$ & $41.61 \mathrm{ab}$ \\
Initial weed infestation for 6WAS & $58.11 \mathrm{abc}$ & $58.79 \mathrm{~b}$ & $30.93 \mathrm{c}$ & $35.53 \mathrm{de}$ \\
Initial weed infestation for 9WAS & $60.78 \mathrm{ab}$ & $62.43 \mathrm{a}$ & $31.47 \mathrm{c}$ & $32.91 \mathrm{e}$ \\
Initial weed infestation for 12WAS & $61.27 \mathrm{a}$ & 62.58 & - & - \\
SE \pm ) & 0.92 & 1.29 & 0.06 & 1.16 \\
Spacing $(\mathrm{cm})$ & & & & \\
60 & $58.32 \mathrm{a}$ & 59.19 & $35.03 \mathrm{a}$ & 37.97 \\
75 & $56.29 \mathrm{a}$ & 57.15 & $34.94 \mathrm{a}$ & 38.78 \\
90 & $55.20 \mathrm{~b}$ & 56.07 & 32.46 & 37.25 \\
SE $( \pm)$ & 0.89 & 1.16 & 0.03 & 0.93 \\
Interactions & & & & \\
Weed x spacing & $*$ & $*$ & $\mathrm{NS}$ & $\mathrm{NS}$ \\
\hline
\end{tabular}

WAS - weeks after sowing; *Significant, NS - Not significant;

- Treatment not completely applied at the time of observation;

Values with the same alphabets within the same column are not significantly different.

Table 3. Effect of period of weed interference and inter-row spacing on number of cowpea planting at early and late seasons

\begin{tabular}{lllll}
\hline Treatments & \multicolumn{2}{l}{ Number of leaves/plant } & \multicolumn{2}{l}{ Leaf area/plant $\left(\mathrm{cm}^{2}\right)$} \\
\cline { 2 - 5 } & $\begin{array}{l}\text { Early season } \\
\text { 9WAS }\end{array}$ & $\begin{array}{l}\text { Late season } \\
\text { 9WAS }\end{array}$ & $\begin{array}{l}\text { Early season } \\
\text { 9WAS }\end{array}$ & $\begin{array}{l}\text { Late season } \\
\text { 9WAS }\end{array}$ \\
\hline Period of Weed Interference & & & & \\
Initial weed removal for 3WAS & $103.56 \mathrm{a}$ & $82.67 \mathrm{c}$ & $86.64 \mathrm{bc}$ & $91.18 \mathrm{~b}$ \\
Initial weed removal for 6WAS & $111.00 \mathrm{a}$ & $1139.00 \mathrm{a}$ & 117.38 & $110.30 \mathrm{a}$ \\
Initial weed removal for 9WAS & $104.00 \mathrm{a}$ & $106.33 \mathrm{ab}$ & $92.06 \mathrm{bc}$ & $118.77 \mathrm{ab}$ \\
Initial weed removal for 12WAS & - & - & $99.93 \mathrm{~b}$ & $108.38 \mathrm{a}$ \\
Initial weed infestation for 3WAS & $109.33 \mathrm{a}$ & $106.00 \mathrm{ab}$ & $102.71 \mathrm{a}$ & $108.14 \mathrm{a}$ \\
Initial weed infestation for 6WAS & $50.67 \mathrm{~b}$ & $100.00 \mathrm{~b}$ & $90.83 \mathrm{bc}$ & $91.71 \mathrm{~b}$ \\
Initial weed infestation for 9WAS & $57.00 \mathrm{c}$ & $58.67 \mathrm{~d}$ & $80.43 \mathrm{c}$ & $86.60 \mathrm{~b}$ \\
Initial weed infestation for 12WAS & - & - & $81.76 \mathrm{c}$ & $88.87 \mathrm{~b}$ \\
SE $( \pm)$ & 1.71 & 3.48 & 7.25 & 3.61 \\
Spacing (cm) & & & & \\
60 & 92.37 & 93.83 & 94.88 & 100.71 \\
75 & 90.92 & 92.29 & 95.02 & 100.46 \\
90 & 88.54 & 89.38 & 92.00 & 100.30 \\
SE $( \pm)$ & 0.82 & 0.82 & 3.71 & 4.08 \\
Interactions & $\mathrm{NS}$ & $\mathrm{NS}$ & $\mathrm{NS}$ & $\mathrm{NS}$ \\
Weed x spacing & & & & \\
\hline
\end{tabular}

WAS - weeks after sowing; *Significant, NS - Not significant;

- Treatment not completely applied at the time of observation;

Values with the same alphabets within the same column are not significantly different. 
In this study, both the pod and grain yields significantly increased with decrease in row width. In both seasons, inter-row spacing of $60 \mathrm{~cm}$ resulted in 32 to $90 \%$ and 30 to 93 increase in cowpea pot and grain yields, respectively compared to 75 and $90 \mathrm{~cm}$ spacing.

There were two obvious advantages in the close spacing. First there was early and better canopy formation coupled with higher plant populations for enhanced weed suppression and crop productivity. For example, plant spaced at $60 \mathrm{~cm}$ had a population of 111,111 plants/ha compared to 88,888 and 74,074 in the case of 75 and $90 \mathrm{~cm}$ inter-row spacing respectively. This observation is similar to that of Paica and Albuguergiu (1970); Ismail and Hall (2001), Busman et al. (2002) and Aliyu (2007). In an experiment conducted by Ismail and Hall (2001) on semi-dwarf and standard height cowpea responses to inter-row spacing $(15,76$, and $102 \mathrm{~cm})$, it was observed that both the semi dwarf and standard height cowpea produced their greatest yields at the narrowest inter-row spacing of $51 \mathrm{~cm}$.

The increase in pod number and length in the wider-spacing may be the result of availability of better growth resources to the individual plants. Also, narrow spacing might cause mutual shading which may cause floral abscission and pod dropping in the lower canopy strata, however, the narrowest spacing gave the highest pod and grain yields probably due to higher plant population density.

There was significant reduction in weed dry matter production in narrow inter row spacing (Table 7). This could be attributed to faster and better canopy cover of the crop under narrow spacing resulting in better suppression of weeds. Reduction in weed bio-mass due to narrow rows has been reported by Burnside (1979); Burdock et.al. (1986); Adigun et al. (1994); Adigun and Aderibigbe (2011).

Table 4. Effect of period of weed interference and inter-row spacing on crop vigour at early and late seasons

\begin{tabular}{|c|c|c|c|c|}
\hline \multirow[t]{3}{*}{ Treatments } & \multicolumn{4}{|c|}{ Crop Vigour Score } \\
\hline & \multicolumn{2}{|c|}{ Early season } & \multicolumn{2}{|c|}{ Late season } \\
\hline & $6 \mathrm{WAS}$ & 9WAS & $6 \mathrm{WAS}$ & 9WAS \\
\hline \multicolumn{5}{|l|}{ Period of Weed Interference } \\
\hline Initial weed removal for $3 \mathrm{WAS}$ & $7.44 \mathrm{a}$ & $7.81 \mathrm{a}$ & $7.44 \mathrm{a}$ & $7.97 \mathrm{a}$ \\
\hline Initial weed removal for $6 \mathrm{WAS}$ & $7.40 \mathrm{a}$ & $7.76 a$ & $7.80 \mathrm{a}$ & $8.17 \mathrm{a}$ \\
\hline Initial weed removal for 9WAS & - & $7.81 \mathrm{a}$ & - & $8.27 \mathrm{a}$ \\
\hline Initial weed removal for $12 \mathrm{WAS}$ & - & - & - & - \\
\hline Initial weed infestation for $3 \mathrm{WAS}$ & $7.53 \mathrm{a}$ & $7.93 \mathrm{a}$ & $7.83 \mathrm{a}$ & $8.24 \mathrm{a}$ \\
\hline Initial weed infestation for $6 \mathrm{WAS}$ & $6.86 \mathrm{a}$ & $7.49 \mathrm{a}$ & $6.98 \mathrm{~b}$ & $7.68 b$ \\
\hline Initial weed infestation for 9WAS & - & $7.43 \mathrm{a}$ & - & $6.38 b$ \\
\hline Initial weed infestation for $12 \mathrm{WAS}$ & - & - & - & - \\
\hline \multirow[t]{2}{*}{$\mathrm{SE}( \pm)$} & 0.20 & 0.02 & 0.21 & 0.41 \\
\hline & $*$ & $*$ & $*$ & $*$ \\
\hline \multicolumn{5}{|l|}{ Spacing $(\mathrm{cm})$} \\
\hline 60 & 7.00 & 7.73 & 7.19 & 7.84 \\
\hline 75 & 6.84 & 7.49 & 7.04 & 7.59 \\
\hline 90 & 6.83 & 7.49 & 7.03 & 7.53 \\
\hline \multirow[t]{2}{*}{$\mathrm{SE}( \pm)$} & 0.05 & 0.01 & 0.05 & 0.03 \\
\hline & NS & NS & NS & NS \\
\hline \multicolumn{5}{|l|}{ Interactions } \\
\hline Weed $\mathrm{x}$ spacing & NS & $*$ & NS & $*$ \\
\hline
\end{tabular}

WAS - weeks after sowing; *Significant ( $\mathrm{p} \leq 0.05)$; NS - Not significant;

Values with the same alphabets within the same column are not significantly different. 
Table 5. Effect of period of weed interference and inter-row spacing on shoot and root dry weight

\begin{tabular}{|c|c|c|c|c|}
\hline \multirow{3}{*}{ Treatments } & \multicolumn{2}{|c|}{ Shoot dry weight (g/plant) } & \multicolumn{2}{|c|}{ Root dry weight (g/plant) } \\
\hline & \multicolumn{2}{|c|}{ 9WAS } & \multicolumn{2}{|c|}{ 9WAS } \\
\hline & Early & Late & Early & Late \\
\hline \multicolumn{5}{|l|}{ Period of Weed Interference } \\
\hline Initial weed removal for $3 \mathrm{WAS}$ & 20.49 cde & $21.44 \mathrm{~b}$ & $2.48 b$ & $3.14 b$ \\
\hline Initial weed removal for $6 \mathrm{WAS}$ & $23.61 \mathrm{abc}$ & $28.77 \mathrm{a}$ & $3.32 \mathrm{a}$ & $4.35 \mathrm{a}$ \\
\hline Initial weed removal for 9WAS & $23.67 \mathrm{abc}$ & $29.54 \mathrm{a}$ & $3.34 \mathrm{a}$ & $4.35 \mathrm{a}$ \\
\hline Initial weed removal for $12 \mathrm{WAS}$ & $25.75 \mathrm{a}$ & $28.86 \mathrm{a}$ & & \\
\hline Initial weed infestation for $3 \mathrm{WAS}$ & $23.84 \mathrm{ab}$ & $29.50 \mathrm{a}$ & $3.31 \mathrm{a}$ & $4.34 \mathrm{a}$ \\
\hline Initial weed infestation for $6 \mathrm{WAS}$ & $21.36 \mathrm{bcd}$ & $23.60 \mathrm{~b}$ & $2.37 \mathrm{~b}$ & $3.24 \mathrm{~b}$ \\
\hline Initial weed infestation for $9 \mathrm{WAS}$ & $18.25 \mathrm{de}$ & $18.67 \mathrm{~b}$ & $2.27 \mathrm{~b}$ & $2.53 b$ \\
\hline Initial weed infestation for $12 \mathrm{WAS}$ & $18.06 \mathrm{e}$ & $18.78 \mathrm{~b}$ & $2.32 \mathrm{~b}$ & $2.55 \mathrm{~b}$ \\
\hline $\mathrm{SE}( \pm)$ & 2.01 & 6.65 & 0.012 & 0.38 \\
\hline \multicolumn{5}{|l|}{ Spacing (cm) } \\
\hline 60 & $23.26 \mathrm{a}$ & 25.71 & $3.12 \mathrm{a}$ & $3.88 \mathrm{a}$ \\
\hline 75 & 21.64 & 24.50 & $2.82 \mathrm{ab}$ & $3.60 \mathrm{ab}$ \\
\hline 90 & $20.74 b$ & 23.71 & $2.61 \mathrm{~b}$ & $3.38 \mathrm{~b}$ \\
\hline \multirow[t]{2}{*}{$\mathrm{SE}( \pm)$} & 0.63 & 0.68 & 0.01 & 0.04 \\
\hline & $*$ & NS & * & * \\
\hline \multicolumn{5}{|l|}{ Interactions } \\
\hline Weed x spacing & NS & $*$ & $*$ & $*$ \\
\hline
\end{tabular}

WAS - weeks after sowing; *Significant, NS - Not significant;

- Treatment not completely applied at the time of observation;

Values with the same alphabets within the same column are not significantly different.

\subsection{Effect of Period of Weed Interference on Growth and Yield of Cowpea and Weed Dry Matter Production}

Weed infestation for only 3 weeks after sowing did not have significant effect on the growth and yield of cowpea growth and yield in both seasons of experimentation. On the other hand, weed removal for only 3 weeks after sowing did not obviate yields loss. This is because weeds during the first 3 WAS were not yet well established and were not aggressive enough in their competitive ability to cause any adverse effect on crop growth and productivity. At this stage weeds with rudimentary root system and few leaves were mostly present and could not cause serious depression on g rowth and yield of the crop. In addition, at the initial stages of crop/growth, both crop and weeds have adequate amount of environmental resources such as light, nutrients and water relative to their individual requirements, hence the crop was not adversely affected. Several workers (Vashney, 1993; Lagoke et al., 1988; Adigun et al., 1991; Adigun et al., 1994; Musa et al., 1996; Naem et al., 2000) have reported that weed infestation for the first 3 WAS did not cause any significant depression in crop growth and yield. In this study, the crop growth parameters mostly affected by initial weed infestation beyond the first three weeks of crop emergence include crop vigour score, canopy diameter, number of leaves, leaf area and shoot and root dry weight (Tables 2 to 6 ) while the yield and components affected were number of pods per plant and pod and grain yields (Tables 2 to 6). It was observed that plots with initial weed removal for the first 6 WAS and beyond had better growth and yield than those obtained from plot initially weed infested for the same period. This shows that early weed removal is more important than the late weed removal. Adigun (1991) observed that the period between 3 and 6 WAS is particularly critical for weed removal in the wet season due to vigorous weed growth and competition with the crops.

In both seasons, the highest cowpea grain yields of (496 and $595 \mathrm{~kg} / \mathrm{ha}$ ) were obtained from plots with initial weed removal for 9 WAS though these were not significantly different from those obtained with initial weed 
removal for 6 WAS (475 and $575 \mathrm{~kg} / \mathrm{ha}$ ) and 12 WAS (459 and $578 \mathrm{~kg} / \mathrm{ha}$ ) as well as initial weed infestation for 3 WAS (435 and $584 \mathrm{~kg} / \mathrm{ha}$ ). This shows that initial weed removal for 6 WAS and beyond were not significantly different in terms of cowpea yield produced (Table 6).

Consequently, initial weed removal at 9 WAS and beyond could not appreciably increase cowpea yields. As a matter of fact further weeding beyond 9 WAS could be detrimental to the crop due to damaging effect of the hoe-weeding on crop roots, leaves and branches as well as reproductive parts such as flowers and pods.

On the other hand the highest cowpea yield losses of about 64 to $68 \%$ were obtained when crop was infested with weeds up to 9 WAS. Moreover, if the crop was allowed to be infested with weeds beyond 6 WAS, subsequent weeding did not improve the crop yield significantly compared to the crop kept weed-infested throughout its life cycle. Weed infestation throughout the crop life cycle resulted in about 64 to $68 \%$ reduction in potential grain yield of cowpea (Table 6). Akobundu (1979) and Le et al. (2004) reported yield losses ranging between 50-86\% due to unchecked weed growth throughout the life cycle in cowpea.

Table 6. Effect of period of weed interference and inter-row spacing on seed weight, pod yield and grain yield in early and late season

\begin{tabular}{|c|c|c|c|c|c|c|}
\hline \multirow{2}{*}{ Treatments } & \multicolumn{2}{|c|}{ 1000-seed Weight (g) } & \multicolumn{2}{|c|}{ Pod Yield (kg/ha) } & \multicolumn{2}{|c|}{ Grain Yield (kg/ha) } \\
\hline & Early & Late & Early & Late & Early & Late \\
\hline \multicolumn{7}{|l|}{ Period of Weed Interference } \\
\hline Initial weed removal for $3 \mathrm{WAS}$ & $131.98 \mathrm{ab}$ & $145.66 \mathrm{a}$ & $334.73 b c$ & $439 b c$ & $295.78 \mathrm{~cd}$ & $265.44 b$ \\
\hline Initial weed removal for $6 \mathrm{WAS}$ & $133.45 \mathrm{a}$ & 148.09 & $665.09 \mathrm{a}$ & 743.78 & $474.88 \mathrm{a}$ & $575.67 \mathrm{a}$ \\
\hline Initial weed removal for $9 \mathrm{WAS}$ & $132.74 \mathrm{a}$ & $149.04 \mathrm{a}$ & 695.46a & 795.33a & $495.58 \mathrm{a}$ & $595.22 \mathrm{a}$ \\
\hline Initial weed removal for $12 \mathrm{WAS}$ & $131.78 \mathrm{a}$ & $146.98 \mathrm{a}$ & $640.87 \mathrm{a}$ & $770.67 \mathrm{a}$ & $458.45 \mathrm{a}$ & $578.11 \mathrm{a}$ \\
\hline Initial weed infestation for $3 \mathrm{WAS}$ & $131.75 \mathrm{a}$ & $148.95 \mathrm{a}$ & $589.93 \mathrm{a}$ & 769.44 & 434.48ab & $584.33 \mathrm{a}$ \\
\hline Initial weed infestation for $6 \mathrm{WAS}$ & $132.52 \mathrm{a}$ & $146.75 \mathrm{a}$ & $454.41 b c$ & $500.94 \mathrm{~b}$ & $365.34 \mathrm{bc}$ & $288.44 b$ \\
\hline Initial weed infestation for $9 \mathrm{WAS}$ & $120.79 \mathrm{c}$ & $130.13 b$ & $285.13 \mathrm{c}$ & $253.78 \mathrm{c}$ & $161.07 \mathrm{~d}$ & $214.22 \mathrm{~b}$ \\
\hline Initial weed infestation for $12 \mathrm{WAS}$ & $122.99 b c$ & $131.51 \mathrm{~b}$ & $237.98 \mathrm{c}$ & $347.56 \mathrm{bc}$ & $202.77 \mathrm{~d}$ & $229.11 b$ \\
\hline \multirow[t]{2}{*}{$\mathrm{SE}( \pm)$} & 1.89 & 4.30 & 72.66 & 125.69 & 51.68 & 113.21 \\
\hline & * & * & * & * & * & * \\
\hline \multicolumn{7}{|l|}{ Spacing $(\mathrm{cm})$} \\
\hline 60 & 13.42 & 14.35 & $672.11 \mathrm{a}$ & $791.25 \mathrm{a}$ & $483.40 \mathrm{a}$ & $527.49 \mathrm{a}$ \\
\hline 75 & 13.48 & 14.49 & $546.57 \mathrm{ab}$ & $620.47 \mathrm{ab}$ & $386.19 \mathrm{a}$ & $418.39 \mathrm{ab}$ \\
\hline 90 & 13.50 & 14.59 & $342.30 \mathrm{~b}$ & $422.38 b$ & $251.05 \mathrm{~b}$ & $336.33 b$ \\
\hline \multirow[t]{2}{*}{$\mathrm{SE}( \pm)$} & 0.07 & 0.07 & 45.88 & 47.47 & 24.04 & 24.03 \\
\hline & NS & NS & $*$ & $*$ & $*$ & $*$ \\
\hline \multicolumn{7}{|l|}{ Interactions } \\
\hline Weed $\mathrm{x}$ spacing & NS & NS & NS & NS & NS & NS \\
\hline
\end{tabular}

WAS - weeks after sowing.

Values with the same alphabets within the same column are not significantly different.

*Significant $(\mathrm{p} \leq 0.05)$.

NS - Not significant.

- Treatment not completely applied at the time of observation. 
Table 7. Effect of period of weed interference and inter-row spacing on weed dry weight and density in early and late seasons

\begin{tabular}{lllll}
\hline \multirow{2}{*}{ Treatments } & \multicolumn{2}{c}{ Weed dry weight $(\mathrm{t} / \mathrm{ha})$} & Weed density $\left(\mathrm{no} / \mathrm{m}^{2}\right)$ \\
\cline { 2 - 5 } & Early & Late & Early & Late \\
\hline Period of Weed Interference & & & & \\
Initial weed removal for 3WAS & $5.23 \mathrm{~b}$ & $6.89 \mathrm{~b}$ & $49.33 \mathrm{de}$ & $77.33 \mathrm{~b}$ \\
Initial weed removal for 6WAS & $4.64 \mathrm{c}$ & $4.10 \mathrm{c}$ & $59.00 \mathrm{bcde}$ & $76.33 \mathrm{~b}$ \\
Initial weed removal for 9WAS & $4.50 \mathrm{c}$ & $4.00 \mathrm{c}$ & $55.23 \mathrm{cde}$ & $73.30 \mathrm{bc}$ \\
Initial weed removal for 12WAS & $4.63 \mathrm{c}$ & $3.87 \mathrm{c}$ & $62.33 \mathrm{bcd}$ & $54.00 \mathrm{~d}$ \\
Initial weed infestation for 3WAS & $4.60 \mathrm{c}$ & $3.77 \mathrm{c}$ & $47.43 \mathrm{e}$ & $62.32 \mathrm{~cd}$ \\
Initial weed infestation for 6WAS & $5.37 \mathrm{~b}$ & $6.90 \mathrm{~b}$ & $84.00 \mathrm{a}$ & $80.67 \mathrm{~b}$ \\
Initial weed infestation for 9WAS & $11.29 \mathrm{a}$ & $14.71 \mathrm{a}$ & $64.33 \mathrm{a}$ & $126.33 \mathrm{a}$ \\
Initial weed infestation for 12WAS & $11.37 \mathrm{a}$ & $14.90 \mathrm{a}$ & $70.33 \mathrm{a}$ & $124.67 \mathrm{a}$ \\
SE $( \pm)$ & 0.35 & $1.25 \mathrm{a}$ & 3.65 & 7.01 \\
& $* *$ & $* *$ & $*$ & $*$ \\
Spacing (cm) & & & & \\
60 & $4.94 \mathrm{~b}$ & 7.04 & $49.25 \mathrm{c}$ & $74.00 \mathrm{c}$ \\
75 & $6.49 \mathrm{ab}$ & 7.31 & $61.88 \mathrm{~b}$ & $81.88 \mathrm{~b}$ \\
90 & $7.93 \mathrm{a}$ & 7.49 & $73.38 \mathrm{a}$ & $97.25 \mathrm{a}$ \\
SE $( \pm)$ & 0.15 & 0.06 & 2.0 & 2.46 \\
90 & $* *$ & NS & $* *$ & $*$ \\
SE $( \pm)$ & & & & $*$ \\
Interactions & & & & \\
Weed x spacing & $*$ & $*$ & $*$ & \\
\hline
\end{tabular}

WAS - weeks after sowing.

Values with the same alphabets within the same column are not significantly different.

*Significant $(\mathrm{p} \leq 0.05)$.

NS - Not significant.

\section{Conclusion}

In conclusion, the results obtained from this study showed that the use of inter-row spacing of $60 \mathrm{~cm}$ resulted in significantly lower weed dry matter production and higher cowpea pod and grain yields than those of 75 and $90 \mathrm{~cm}$ spacing. Initial weed infestation of up to 3 WAS did not have any adverse effect on crop growth and yield provided weeds are subsequently removed. Similarly, cowpea yield loss was not significantly averted by keeping the crop weed free for only 3 WAS without subsequent weed removal. In order to obtain optimum yield similar to the weed free cowpea field, it was required to keep the crop weed free for 6 to 9 WAS. Also, frequent weeding beyond 9WAS could result in reduction in cowpea yield due to mechanical damage of hoe weeding. The practical implication of this finding is that early weeding starting from 3WAS is very crucial in cowpea production and for optimum pod and grain yield the crop requires weed removal between 3 and 9 WAS.

\section{References}

Adigun, J. A. (1992). Effect of intra-row spacing and nitrogen on the response of tomato (Lycospersicon esculentus Mill) to weed interference and management in the Nigeria savanna. Ph.D. thesis, Ahmadu Bello University, Nigeria.

Adigun, J. A. (2002). Chemical weed control in transplanted rain fed tomato (Lycoperiscon esculentus Mill) in the forest-Savanna transition zone of south western Nigeria. ASSET, 2(2), 141-150. 
Adigun, J. A., \& Lagoke, S. T. O. (2003). Assessment of critica 1 period of weed interference in transplanted rainfed and irrigated tomatoes in the Nigerian Northern Guinea Savanna. Nigerian Journal of Plant Protection, 21, 89-100.

Adigun, J. A., Lagoke, S. T. O., Kumar, V., \& Erinle, I. D. (1994). Effect of intra- row spacing, nitrogen level and period of weed interference on growth and yield of transplanted tomato (Lycopersicom esculentum Mill) in the Nigerian savanna. Samaru Journal of Agricultural Research, 11, 31-42.

Akobundu, I. O. (1979). An Evaluation of Selected Cowpea Cultivars fr Herbicide Tolerance. Proceeding of the $9^{\text {th }}$ annual conference of Weed Science Society of Nigeria (pp. 69-74).

Alagbejo, M. D. (1987). Identification of a weed host of pepper veinal mottle virus in Northern Nigeria. Samaru Journal of Agricultural Research, 5, 65-70.

Aliyu, B. S. (2007). Evaluation of the effect of intra- and inter-row mixing of pearl crop yield in Striga hermonthica (Del) Benth infested field infested. International Journal of Pakinstan Agricultural Science, 1, 1- 4 .

Asiwe, J. A. N., \& Kutu, R. F. (2007). Effect of plant spacing on yield weeds insect infestation and leaf bright of Bambara groundnut. Proceedings of African Crop Science Society, 4, 1947-1950.

Biswan, D. K., Haque, M. M., Hamid, A., Ahmed, J. U., \& Rahman, M. A. (2002). Influence of plant population density on growth and yield of two black gram varieties. Pakistan Journal of Agronomy, 3, 83-85.

Buchaman, G. A., Haser, E. W., Ethredge, W. J., \& Ceal, S. R. (1976). Competition of Florida Beggar weed and sickle pod with peanuts II. Effect of cultivation on weeds and SAOH. Weed Science, 24, 29-39.

Burnside, O. C., \& Juricek, C. (1967). Weed removal studies in soyabean. Proceedings North Central Weed ControlConference, 24, 159-160.

Cooper, R. I. (1985). Breeding semi-dwarf beans. Plant Breeding Reviews, 3, 289-311.

Dowson, J. H. (1970). Time and Duration of weed interference in rebition to crop-weed competition. Proceedings $3^{\text {rd }}$ weed control conference (pp. 13-35).

Friesen, G. H. (1979). Weed interference in transplanted tomatoes (Lycopersicon esculentum Mill). Weed Science, 27(1), 11-13.

Henshaw, F. O., Mcwatters, K. H., Akingbola, J. O., \& Philips, R. D. (2005). Sensory properties of Akara (fired cowpea paste). Proceedings of first int. Conf. of Edible legumes, Preforis, Durban, April 17-21, 2005.

Ismail, A. M., \& Hall, A. E. (2001). Semi-dwarf and standard-height cowpea responses to row spacing in different environments. Univ. Of California Div Agric. Nat. Res. Publ., 95, 5-52.

Lagoke, S. T. O., \& Shebayan, J. A. Y. (1988). Effectiveness and economics of chemical weed control in cowpea (Vigna unguiculata (L) Walp) in the Northern Guinea Savanna of Nigeria. Samaru Journal of Agricultural Research, 6(4), 333-342

Le, R., Guidong, Z., Yumei, Z., \& Zhan, Z. (2004). Damage loss and control Technology of weeds in cowpea field. Weed science, 2, 25-26.

Naeem, M., Ahmad, S., \& Ali, H. (1999). Investigation on the critical period of weed interference with the growth and yield of mungbean. International Journal of Agriculture and Biology, 1(4), 350-352.

Paiva, J. B., \& Albuquerque, J. J. L. (1970). Espacamento emfeijaorde corda (Vigna sinensis End) No ceara. Turribalba, 20(4), 413-414.

Quin, F. M. (1997). Advances in cowpea Research.

Street, J. E., Buchanan, G. A., Crowley, R. H., \& Mcguive, J. A. (1981). Influences of cotton (Gossypium hirsutum) densities on competitiveness of pig weed (Amaranthus spp) and sickle pod (Cassia obstusifolia). Weed science, 29(3), 253-256.

Tarawali, S. A., Singh, B. B., Peters, M., \& Blade, S. F. (1997). Cowpea haulms as fodder. Advances in Cowpea Research, 313-325.

Teasday, J. R., \& Frank, J. R. (1983). Effect of row spacing on weed competitions with snap beans (Phaseolus vulgaris). Weed science, 31(1), 81-85. 
Usman, A., Elemo, K. A., Lagoke, S. T. O., \& Adigun, J. A. (2002). Nitrogen and weed management in maize intercropped with upland rice. Journal of Sustainable Agriculture, 21(1), 5-16. http://dx.doi.org/10.1300/J064v21n01_03

Varshney, J. G. (1993). Weed management in pigeon pea and green gram intercropping Indian Journal of Agricultural science, 63, 4-7.

\section{Copyrights}

Copyright for this article is retained by the author(s), with first publication rights granted to the journal.

This is an open-access article distributed under the terms and conditions of the Creative Commons Attribution license (http://creativecommons.org/licenses/by/3.0/). 